\title{
An Assessment of Operation Safe Place
}

\section{Paul Holtom *}

\section{Background}

In April 2002, the Southeast European Cooperative Initiative (SECI) Regional Centre for Combating Trans-border Crime ${ }^{1}$ established a sub-group within its Anti-Terrorism Task Force to "prevent, detect, trace, investigate, and suppress illicit trafficking in small arms and light weapons (SALW) by establishing direct, sustainable, and rapid channels of information exchange." ${ }^{2}$ This sub-group consists of a network of police and customs officers from South Eastern Europe (SEE), who share intelligence on illicit SALW seizures. Saferworld, an independent NGO based in the U.K. that works to prevent armed violence around the world, has highlighted the work of the SECI Centre's SALW Task Force as an example of good practice in regional cooperation for combating trafficking in SALW. ${ }^{3}$

As the lead state in this initiative, Albania proposed setting up an international operational intelligence information exchange on seizures of illicit small arms in 2002, and nominated the SECI Centre as an operational coordination unit. This proposal matured into the SALW seizure information exchange, known as Operation Ploughshares, which was launched in November 2002 and ran for six months. The primary objective of the information exchange was the collection of data that could be analyzed to give an account of the scope and dynamics of illicit SALW trafficking in the region. The following five SECI states actively participated in Operation Ploughshares: Albania, Bulgaria, Macedonia/FYROM, Moldova, and Turkey.

According to an analysis report on Operation Ploughshares, written by the U.K.'s National Criminal Intelligence Service (NCIS), data on trafficking of 493 small arms, just under twenty thousand rounds of ammunition, more than fifty mines, and several kilograms of explosives were exchanged during the operation. ${ }^{4}$ However, the report concluded that the information was "too scant to allow meaningful analysis," and recommended that future information exchange exercises should endeavor to include information on:

- Seizure localities

* Dr. Paul Holtom is a Research Fellow at the Centre for Border Studies at the University of Glamorgan. The author wishes to thank Saferworld and, in particular, Simon Rynn, for their help.

1 Hereafter referred to as SECI Centre.

2 Saferworld Briefing Paper, The SECI Centre's Activities in Combating Firearms Trafficking in South Eastern Europe (SEE), 30 November 2004.

3 Ibid.; Andy Maclean, Bernardo Mariani, and Alex Vatanka, "Enhancing EU Action to Prevent Illicit Small Arms Trafficking,” in Small Arms and Light Weapons Transfers (Geneva: United Nations Institute for Disarmament Research, 2005).

4 National Criminal Intelligence Service, “Analysis Report: Task Force-Combating Trafficking on Small Arms, Light Weapons and Explosives: Operation Ploughshares,” May 2003. 
- Methods of transportation and concealment when smuggling SALW

- Those suspected of, and arrested for, involvement in arms trafficking

- Links to organized crime.

It was envisaged that such information would help to identify vulnerable border crossings, time frames favored by smuggling groups, and preferred routes.

Despite these weaknesses, Saferworld has argued that Operation Ploughshares should be regarded as a successful cooperative venture for a first attempt at organizing an exchange of information on SALW being trafficked in Southeastern Europe. At the same time, the resource limitations of the SECI Centre-in particular, a lack of sufficient analytical capacity to effectively examine the data collected on SALW trafficking, inexperience in project management, and a number of deficiencies made evident by Operation Ploughshares - were highlighted by Saferworld's report.

The recommendations and lessons alluded to above were taken into consideration when Albania proposed another information exchange on seizures of SALW during a joint Saferworld/SECI Centre meeting in Tirana in December 2004. It was decided that each participating state in this information exchange should designate a contact person to help facilitate inter-state cooperation in relation to combating illicit arms trafficking. One of the main aims of Operation Ploughshares' successor, Operation Safe Place, was to identify specific individuals and groups engaged in the illegal trade, transfer, and possession of illicit SALW.

It was also hoped that Operation Safe Place would yield a significant body of data on the types of goods being trafficked and on who was doing the trafficking, with the results being distributed throughout the region. A proposal was also made for the collected data to be stored in a regional database. To assist with these aims, a standard reporting form was drafted, on which details of seizures of SALW at border crossing points could be entered, as well as listings of weapons acquired by state agencies that were not produced within the state in which they were found, surrendered, or seized. The data requested on these standard forms included:

- Details of the SALW, ammunition, and explosives seized including: country of origin; make; serial number; number of units; etc.

- Location and date of seizure, including knowledge of the route of entry and/or proposed exit

- Means of carriage and information on concealment

- Details of the person arrested, e.g. nationality.

One can see that the information requested on these forms included information that the U.K.'s NCIS report on Operation Ploughshares had identified as important for analyzing trafficking patterns.

By 30 May 2005, seven SECI states had reportedly exchanged information with SECI under the rubric of Operation Safe Place. ${ }^{5}$ These states were: Albania, Bosnia

5 SALW SECI Centre Task Force, "Quarterly Progress Report on Operation Safe Place (March-May 2005).” 
and Herzegovina, Greece, Macedonia/FYROM, Moldova, Romania, and Turkey. Slovenia had also agreed to participate in the information exchange and, although it was not included in the list of participants in SECI's "Quarterly Progress Report on Operation Safe Place," Slovene authorities forwarded information on arms seizures to the SECI centre in Bucharest in June 2005.

The rest of this briefing paper is devoted to considering a selection of the data gathered during Operation Safe Place, which ran from March until September 2005. The data received for analysis were not comprehensive, and differed in quantity, quality, and formatting for each state. Therefore, this report will highlight a selection of issues from the data supplied to the SECI Centre by each participating state, before concluding with several general comments.

\section{Results of Operation Safe Place}

\section{Albania}

At the very start of Operation Safe Place, a joint investigation carried out by Albanian, Macedonian, and Montenegrin police forces provided a good example of inter-state cooperation to foil an attempt to ship illicit explosives from Montenegro through Albania to clients in Macedonia. An undercover sting operation, in which Albanian police officers infiltrated a criminal group that planned to sell C4 explosives to a customer in Macedonia, resulted in the seizure of six cell phone-triggered bombs, a Beretta pistol, and ammunition. Four men were arrested in Albania in connection with this smuggling ring, and at least one arrest was made in Montenegro.

In addition, details of the makes and serial numbers of sixteen pistols and two rifles were sent to the SECI Centre. Of the sixteen pistols, five were Zastava, while other included a Mauser, Beretta, Glock, Browning, Skorpion, and Voltran M-88. No details were made available for analysis on the location of these seizures or individuals involved in these cases.

\section{Bosnia and Herzegovina}

According to a quarterly report on Operation Safe Place, officials in Bosnia and Herzegovina had informed SECI of numerous seizures of small arms, ammunition, and explosives in the first months of Operation Safe Place. ${ }^{6}$ The report stated that information had been received on the types of firearms, as well as their makes and serial numbers, along with data on the individuals arrested in connection with possession or trafficking in these materials. No information on links to organized crime groups were made explicit at this time, and no information on this has been received for the compilation of this report.

From the data made available for analysis, it is not possible to comment on the total number of seizure incidents that yielded a sum of 2,877 small arms, 338,289 rounds of ammunition, and assorted artillery shells, mines, grenades, and other explosive devices. However, from the tables of collated data on illicit SALW recovered in Bosnia and

6 Ibid. 
Herzegovina during Operation Safe Place, it is possible to make the following general comments:

- Only 33 percent of SALW reported were seized during police operations - the remaining two-thirds were recovered through voluntary hand-overs.

- The ratio of automatic weapons seized was relatively constant between police operations and the total number of seizures; 49 percent of the weapons recovered in police operations were automatic rifles (including M.48 rifles), compared to a total of 52 percent of all seized SALW.

- Handguns accounted for 18 percent of the total SALW haul, but represented 26 percent of those weapons seized in police operations. These figures include sixteen homemade pistols recovered by police (one was seized by police; fifteen were voluntarily surrendered).

\section{Greece}

During Operation Safe Place, Greece reported eight seizure incidents involving small arms of non-Greek origin. Four of these cases were discovered in Crete, three were in Athens, and one in Thessalonika. No seizures at border crossings were reported to SECI. Five of the incidents involved only Greek citizens, two incidents involved only Albanian citizens, and one incident involved both Greek and Albanian citizens.

Two of the discoveries in Crete took place in residences on the island, while two of the seizures in Athens followed car searches, one of which was reportedly a stolen vehicle being driven by Albanian citizens. There was no information on suspected links to organized crime groups in any of the reported cases.

Twenty-six weapons were reported in total, with the origins of five of these small arms unknown. The origins of the rest of the weapons seized are shown in the table below:

\begin{tabular}{ll}
\hline Origins of SALW & No. of Units \\
\hline Russia/USSR & 4 \\
\hline USA & 4 \\
\hline Germany & 3 \\
\hline UK & 3 \\
\hline Italy & 2 \\
\hline Czech Republic / Czechoslovakia & 2 \\
\hline Belgium & 1 \\
\hline France & 1 \\
\hline Yugoslavia & 1 \\
\hline
\end{tabular}


The majority of the weapons seized were handguns-five revolvers and ten pistols - although eleven rifles and machine guns were also seized. A variety of different types and makes of light weapons were recorded, including two Russian/Soviet Kalashnikovs and two German Luger pistols.

\section{Macedonia}

SECI's quarterly report on Operation Safe Place stated that persons residing in FYROM and Kosovo had been arrested in connection with more than one hundred seizures of small arms, ammunition, and explosives during the six months in which the operation was in place. ${ }^{7}$ Seventy-six individuals were named in the reports received by SECI, which also gave details of the region of the seizure, and in many cases details of the type of weapons, quantity, make, and date of seizure. In several cases, information was also provided on the origins of the arms. The information provided suggests that a number of pistols originated in Serbia \& Montenegro, Italy, Germany, and Belgium, with one Spanish-made pistol also highlighted. The origins of the automatic rifles that were given indicate that China, Russia, and Yugoslavia were the producing states for the majority of these types of seized weapons. It is not clear how many seizures took place at border crossing points, but it is possible to give a breakdown of the most common sites for SALW seizures in Macedonia:

\begin{tabular}{lc}
\hline Area of Seizure & No. of Units \\
\hline Skopje & 21 \\
\hline Tetovo & 12 \\
\hline Struga & 10 \\
\hline Village of Blace & 10 \\
\hline Stip & 9 \\
\hline Veles & 6 \\
\hline Kicevo & 5 \\
\hline Vinica & 5 \\
\hline
\end{tabular}

In addition, the villages of Bosilevo, Brest, Buzalkovo, Celopek, Kocilari, Prosevo, Rzanicino, Selce, Selica, and Terance yielded a total of twenty weapons.

Overall, 317 seized small arms were reported to the SECI Centre, including: 4 revolvers, 65 pistols, 35 rifles/MG, 35 hunting rifles and carbines, 175 automatic rifle frames (all reported in one seizure incident), 1 homemade rifle, and 2 rifle barrels. More than twenty different makes of pistols were recovered, although 25 of the 65 recovered were produced by Crvena Zastava. Serial numbers for seventeen of the weapons seized were not reported, although it is not explicitly stated if identifying marks had been deliberately removed. No details of associations between the individuals ap-

7 Ibid. 
prehended for SALW violations and organized crime were explicitly referred to in the data made available for analysis.

\section{Moldova}

Moldovan customs officials informed SECI that two individuals were apprehended trying to smuggle grenades from Moldova into Romania on a train, and that a total of 295 grenades were reported seized in Moldova during Operation Safe Place. ${ }^{8}$ The regional breakdown of seizures of light weapons, grenades, and explosives reveals that Moldovan Interior Ministry officers also recovered 39 weapons, 31,493 rounds of ammunition, and almost $1.5 \mathrm{~kg}$ of explosives. No information was made available for analysis on the total number of seizure incidents, those involved, the origins of the materials seized, the destinations if seized in transit, or serial numbers.

\section{Romania}

Data on six seizures of light weapons, ammunition, and explosive devices, and two discoveries of abandoned weapons were reported to SECI by Romanian contacts. The two discoveries of abandoned arms and ammunition were reported by the Romanian Interior Ministry officers, while the six seizures all took place at Romanian border crossing points, including one case at the airport in Timisoara.

Information on the incidents at border crossings included type of weapon or explosive device, the origins for four weapons (three from the U.S. and one from the Czech Republic), the route being taken, and the names and nationality of those arrested:

- Percussion caps for light missiles were seized at the Nadlac border crossing on the Romanian-Hungarian border on 5 March 2005. A Dutch citizen was arrested.

- Three grenades were seized on the Chisinau-Bucharest train on 8 April 2005. Two Moldovan citizens were arrested.

- A gas pistol was abandoned between the customs offices of Romania and Hungary at the Nadlac-Nagylak border crossing on 11 April 2005. A Moldovan citizen was arrested, and the route taken was believed to be from Macedonia to Romania to Hungary.

- A gun was seized at the Calafat border crossing between Bulgaria and Romania on 10 July 2005. An Italian citizen was arrested, and the route taken was believed to be from Italy to Bulgaria to Romania.

- A gun, which was discovered in a make-up kit, was seized at the Sculeni border crossing on 16 July 2005. A Czech citizen was arrested, whose itinerary was believed to be: Czech Republic-Romania-Macedonia- USA.

- A pistol and cartridges were found in a travel bag by Romanian customs officers at the Timisoara airport. The Swiss citizen arrested was planning to board a flight to Geneva.

In four of these cases, cars had been the means of carriage for the arms, ammunition, and explosives seized.

8 Ibid. This case is also referred to below in the Romanian section of this report. 
Reports revealed that there had been attempts to remove identifying marks from two of the weapons found abandoned in Galati. In all other cases, no attempts had been made to remove such marks. No references were made on the report sheets of associations with organized crime groups.

\section{Slovenia}

A report was sent to SECI on 14 June 2005 regarding a shipment of sixteen automatic weapons that arrived in Ljubljana on a flight from Prague on 13 May 2005. The consignment contained:

- Five Thompson M1928 A1 machine guns

- Nine CZ M56 submachine gun

- One CZ VZ 26

- One CZ VZ 24.

The recipient of the consignment, a resident of Slovenia with permission to import weapons and explosives, did not have the necessary documentation for the import of this particular consignment. The shipment was temporarily seized by Slovenian authorities while they contacted the Czech authorities to acquire the necessary export documentation and verify that the exporting company, B.V.S. s.r.o., was registered in the Czech Republic and authorized to export arms and ammunition. Following their initial enquiries, the Slovenian authorities had reason to doubt the existence of the exporting company. They reportedly had reason to believe that the shipment was illegally imported to the Czech Republic from Southeastern Europe, before being transferred into Slovenia. It is unclear at the time of writing this report if any other information had been received on this case by the SECI Centre.

\section{Turkey}

Thirty-six seizure reports were filed with SECI by Turkish authorities, with thirty of the reports relating to seizures of small arms and ammunition, five cases involving only ammunition, and one case involving $920 \mathrm{~g}$ of C-4 plastic explosive. Only one of the reports was filed on an incident that did not take place at a border crossing point. Twenty-five of the twenty-nine SALW seizures that took place at border crossings occurred at the Habur crossing on the Iraq-Turkey border. This border crossing point accounted for 104 of the 121 seized weapons reported to SECI by Turkey during Operation Safe Place. The four other seizures that took place at border crossings occurred at:

- Kapikule crossing (Turkey-Bulgaria border), at which one seizure occurred, yielding one weapon

- Akçakale crossing (Turkey-Syria border), at which one seizure occurred, yielding ten weapons

- Ipsala crossing (Turkey-Greece border), at which two seizures occurred, yielding four weapons and one weapon respectively.

In addition, one non-Turkish light weapon was seized in an office in Istanbul. All cases were discovered by Turkish customs officers, although the seizure at the Akçakale border crossing on 24 April 2005 was a joint operation between customs and 
police officers. The majority of those arrested in connection with these seizures were Turkish males, although there were four separate incidents in which one Austrian, one British, one German, and one Dutch citizen were arrested.

The reports that mentioned the means of transportation by which the seized weapons were conveyed cited eighteen seizure incidents in cars, nine in oil tankers, three in trucks, and two in pick-up trucks. Of these seizures, twenty cases yielded only a single weapon, with the following cases notable for seizures of multiple arms:

- 57 light weapons discovered in an oil tanker inspected at the Habur border crossing on 4 March 2005

- 7 small arms discovered in an oil tanker inspected at Habur on 19 April 2005

- 3 weapons discovered in an oil tanker inspected at Habur on 26 April 2005

- 3 weapons discovered in an oil tanker inspected at Habur on 28 May 2005

- 6 weapons discovered in a truck inspected at Habur on 5 April 2005

- 6 weapons discovered in a car inspected at Habur on 1 April 2005

- 10 weapons discovered at the Akçakale border crossing on 24 April 2005

- 4 weapons discovered in a car inspected at the Ipsala border crossing on $12 \mathrm{Au}-$ gust 2005.

From this very small sample, one could hypothesize that oil tankers passing through the Habur border crossing between Iraq and Turkey appear to be a favored mode of transport for SALW traffickers moving between Turkey and Iraq. Small arms were reportedly hidden in various parts of the oil tankers and trucks reported on by Turkish officials, ranging from driver's compartments and personal belongings to headlights and storage units.

However, two-thirds of the SALW seizure incidents reported involved a single handgun, leading one to assume that these may not be cases of arms trafficking for sale, but rather the illegal possession of light weapons for personal protection for traveling the dangerous route between Iraq and Turkey. There was no information of other illicit cargoes seized at the same time as the small arms and ammunition in these cases, which could of course give rise to a number of alternative explanations for the unregistered weapons.

There were more than twenty different makes of pistols represented in the reports overall, of different caliber and origins. The following is a brief summary of the most common types of firearms reported: 23 Austrian Glock handguns, 15 Belgian Browning handguns, 12 Italian Berettas, 6 Czech VZOR handguns, 5 Czech CZ handguns, 2 Argentine Browning handguns, 2 Russian AK-47s, and 3 SMG pump-rifles.

\section{General Comments on Operation Safe Place}

Operation Safe Place was quantitatively superior to Operation Ploughshares, in that more SECI states participated in the information exchange, and data on a larger number of seizures, SALW, ammunition, and explosives were shared in the process. The table below is a simple collation of the reports of 3,423 seizures of SALW units, almost 400,000 rounds of ammunition, more than 30,000 artillery shells, and thousands 
of other explosive devices submitted to the SECI Centre during Operation Safe Place.

However, there have been a number of problems in compiling this report. First, the quality of the information provided by participating states has not been of the same standard. For example, while a standardized reporting form was drawn up for use in Operation Safe Place, only copies of the reporting forms provided by Bosnia and Herzegovina, Greece, Romania, and Turkey were made available for analysis - with the Bosnian and Greek submissions not made available in English. This has therefore hampered the comparative analysis of different state submissions, and has also meant that there has been richer analysis of some states at the expense of others.

However, to their credit, the standardized report sheets made available for analysis filled in many of the intelligence gaps identified in the conclusions of the U.K.'s NCIS analysis of Operation Ploughshares. The standardized report sheets requested information not only on the weapons, ammunition, and explosives seized, but also on seizure locations, routes, methods of transportation and concealment, and suspects. Therefore, the report sheets filed by Bosnia and Herzegovina, Greece, Romania, and Turkey with the SECI Centre contained information in most of these categories, thereby no doubt providing more data for analysis than was gathered during Operation Ploughshares.

Of course, the data contained in these report sheets tend to be of a very preliminary nature. It is hoped that the exchange of these report sheets is of benefit to legal proceedings taken against those violating national firearms laws in which international cooperation is necessary, but Operation Safe Place had other aims as well.

One of the stated aims of Operation Safe Place was not only to exchange information and collect data, but also to produce a regional database in which meaningful analysis of trafficking patterns and traffickers could be stored. For these cases to be useful for analysis, however, it would be necessary to update the cases outlined in the

Table 1: Total SALW Reported to SECI During Operation Safe Place (March-September 2005)

\begin{tabular}{lcrrrrrrrr}
\hline & AL & BiH & GR & MAC & MOL & ROM & SLO & TU & Total \\
\hline Revolver & & 8 & 5 & 4 & & 4 & & 115 & 136 \\
\hline Pistol & 16 & 490 & 10 & 65 & 19 & & & & 584 \\
\hline $\begin{array}{l}\text { Homemade } \\
\text { Pistol }\end{array}$ & 16 & & & & & & & 16 \\
\hline $\begin{array}{l}\text { Rifle/ } \\
\text { Machine Gun }\end{array}$ & 2 & 1970 & 11 & 35 & 20 & 6 & 15 & 6 & 2048 \\
\hline $\begin{array}{l}\text { Homemade rifle } \\
\text { Machine Gun }\end{array}$ & 51 & & 1 & & & & & 52 \\
\hline $\begin{array}{l}\text { Hunting Rifle/ } \\
\text { Carbine }\end{array}$ & 92 & & 35 & & & & & 127 \\
\hline Parts of SALW & & & 177 & & & & & 177 \\
\hline Other SALW & 250 & & & & & & & & \\
\hline TOTAL & 18 & 2877 & 26 & 317 & 39 & 10 & 15 & 121 & 3423 \\
\hline
\end{tabular}


reporting forms with information that subsequently comes to light during further investigations and legal proceedings. This is because it is likely that information on others involved in the acquisition or trafficking of the seized weapons, the routes that have been or were planned to be used, and of course, links to organized crime groups would be revealed or discovered at these later stages. It is worth noting that exploring links to organized crime was to be one of the explicit aims of Operation Safe Place, yet not a single report sheet analyzed for this report commented upon links between those arrested and organized crime or wider arms trafficking networks. The failure to meet this aim is probably due to the rapid submission of raw data, as well as the fact that many of the seizures reported were of a very small scale. Perhaps Operation Safe Place only succeeded in weeding out some of the "small fry," and was unable to successfully locate, infiltrate, and uncover organized trafficking rings during Operation Safe Place's term.

Overall, from the data made available for analysis, the majority of seizures recorded appeared to consist of no more than a very small number of handguns or hunting rifles (often only one). Furthermore, there were very few cases in which identifying marks had been removed from the weapons seized, a hallmark of more organized arms trafficking rings. While a large number of pistols seized in Macedonia were produced by Crvena Zastava, they are certainly not the only arms producer to have had illicit small arms reported seized during Operation Safe Place. Pistols, revolvers, automatic rifles, and other SALW from all major arms-producing states have been recovered during Operation Safe Place. How they made their way to the region has not been made explicitly clear in the report sheets, but the snapshot provided by the SALW seizures in the eight participating states shows that it is not only the former Soviet bloc states that provide arms to the region.

Operation Safe Place also suffered from the fact that only eight of SECI's member states actively participated in the information exchange exercise. The absence of EU applicant states from the region, such as Bulgaria, Croatia, Serbia, and Montenegro, also makes the task of analyzing regional arms trafficking patterns difficult. The fact that these states have maintained sizeable arsenals and arms production facilities makes their absence even more lamentable. The Slovenian request for assistance also highlighted the benefits that could be achieved by including other EU member states in the wider neighborhood of Southeastern Europe into future information exchanges.

Undoubtedly, this operation will be regarded as another step forward in the struggle to coordinate efforts to combat arms trafficking in Southeastern Europe. Contact points for the participating SECI states were clearly identified, and it is to be hoped that these posts remain active beyond the time period of Operation Safe Place. They could potentially serve as a national SALW focal points, reportedly one of the weak points of the RIP Framework for the Stability Pact. At the same time, if SECI is to serve as an efficient focal point for coordinating future information exchange exercises and data analysis, it is obvious that it requires the necessary funds and personnel to carry out these tasks. Greater cooperation by a larger number of SECI member states in future information exchange exercises would also show signs of a greater commitment to improving regional security and combating arms trafficking. 


\section{Bibliography}

Maclean, Andy, Bernardo Mariani, and Alex Vatanka. "Enhancing EU Action to Prevent Illicit Small Arms Trafficking." In Small Arms and Light Weapons Transfers . Geneva: United Nations Institute for Disarmament Research, 2005. 